\title{
Titrimetric and spectrophotometric assay of diethylcarbamazine citrate in formulations using iodate and iodide mixture as reagents
}

\author{
Nagaraju Swamy, Kudige Nagaraj Prashanth, Kanakapura Basavaiah" \\ Department of Chemistry, University of Mysore, Manasagangotri, Mysuru, Karnataka, India.
}

\begin{abstract}
One titrimetric and two spectrophotometric methods are proposed for the determination of diethylcarbamazine citrate (DEC) in bulk drug and in formulations using potassium iodate and potassium iodide as reagent. The methods employ the well-known analytical reaction between iodate and iodide in the presence of acid. In titrimetry (method A), the drug was treated with a measured excess of thiosulfate in the presence of unmeasured excess of iodate-iodide mixture and after a standing time of $10 \mathrm{~min}$, the surplus thiosulfate was determined by back titration with iodine towards starch end point. Titrimetric assay is based on a 1:3 reaction stoichiometry between DEC and iodine and the method is applicable over $2.0-10.0 \mathrm{mg}$ range. The liberated iodine is measured spectrophotometrically at $370 \mathrm{~nm}(\operatorname{method} \mathrm{B})$ or the iodine-starch complex measured at $570 \mathrm{~nm}$ (method C). In both methods, the absorbance is found to be linearly dependent on the concentration of iodine, which in turn is related to DEC concentration. The calibration curves are linear over 2.5-50 and 2.5-30 $\mu \mathrm{g} \mathrm{mL}^{-1}$ DEC for method B and method C, respectively. The calculated molar absorptivity and Sandell sensitivity values were $6.48 \times 10^{3} \mathrm{~L} \mathrm{~mol}^{-1}$ $\mathrm{cm}^{-1}$ and $0.0604 \mu \mathrm{g} \mathrm{cm}^{-2}$, respectively, for method $\mathrm{B}$, and their respective values for method $\mathrm{C}$ are $9.96 \times 10^{3} \mathrm{~L} \mathrm{~mol}^{-1} \mathrm{~cm}^{-1}$ and $0.0393 \mu \mathrm{g} \mathrm{cm}^{-2}$. The intra-day and inter-day accuracy and precision studies were carried out according to the $\mathrm{ICH}$ guidelines. The methods were successfully applied to the analysis of DEC formulations.
\end{abstract}

Uniterms: Diethylcarbamazine citrate/determination. Titrimetry/quantitative analysis. Spectrophotometry/ quantitative analysis. Pharmaceutical formulations/analysis.

Propõem-se titulação e dois métodos espectrofotométricos para a determinação de citrato de dietilcarbamazina (DEC) a granel e em suas formulações, usando iodato de potássio e iodeto de potássio como reagente. Os métodos utilizam a reação analítica conhecida entre iodato e iodeto, na presença de ácido. Na titulometria (Método A), o fármaco foi tratado com excesso medido de tiossulfato, na presença de excesso não medido de mistura iodato-iodeto e, depois de um tempo de repouso de $10 \mathrm{~min}$, o excesso de tiossulfato foi determinado por titulação de retorno com iodo até o ponto final com amido. A titulação é baseada em reação com estequiometria 1:3 entre DEC e iodo e o método é aplicável na faixa de 2.0$10.0 \mathrm{mg}$. O iodo liberado é medido espectrofotometricamente a $370 \mathrm{~nm}$ (método B) ou o complexo de iodo-amido medido a $570 \mathrm{~nm}$ (método C). Em ambos os métodos, a absorvância é considerada linearmente dependente da concentração de iodo, a qual, por sua vez, está relacionada à concentração de DEC. As curvas de calibração são lineares para concentrações de DEC de $2.5-50$ e $2.5-30 \mathrm{mg} \mathrm{mL}^{-1}$ para o método $\mathrm{B}$ e para o método $\mathrm{C}$, respectivamente. A absortividade molar calculada e os valores de sensibilidade Sandel foram $6.48 \times 10^{3} \mathrm{~L} \mathrm{~mol}^{-1} \mathrm{~cm}^{-1} \mathrm{e} 0.0604 \mathrm{ug} \mathrm{cm}^{-2}$, respectivamente, para o método B, e os seus respectivos valores para o método C são $9.96 \times 10^{3} \mathrm{~L} \mathrm{~mol}^{-1} \mathrm{~cm}^{-1} \mathrm{e} 0.0393 \mathrm{mg} \mathrm{cm}^{-2}$. Os estudos de exatidão e precisão intra-dia e inter-dia foram realizados de acordo com as diretrizes da $I C H$. Os métodos foram aplicados com sucesso na análise de formulações de DEC.

Unitermos: Citrato de dietilcarbamazina/determinação. Titulometria/análise quantitativa. Espectrofotometria/análise quantitativa. Formulações farmacêuticas/análise.

*Correspondence: Kanakapura Basavaiah. Department of Chemistry, University of Mysore. Manasagangotri, Mysuru-570006, Karnataka, India. Tel.: +918212419659. Fax:+91-8212516133. E-mail: kanakapurabasavaiah@gmail.com 


\section{INTRODUCTION}

Diethylcarbamazine citrate (DEC) [Figure 1], chemically known as [N,N-diethyl-4-methyl-1piperazinecarboxamide citrate] is an anthelmintic agent used in the treatment of filarial infections caused by a host of organisms commonly found in the tropics (Swinyard, 1990). It is also the alternative drug of choice in Onchocerca volvulus infections and tropical eosinophilia (Adkiwu, Ofokansi, Attama, 1999). The drug is official in British Pharmacopoeia [BP] (1988), which describes a nonaqueous titration method for its determination and also official in the United States Pharmacopoeia [USP] (United States Pharmacopoeia, Monographs), which uses a liquid chromatographic technique with phosphate buffer system for the assay.

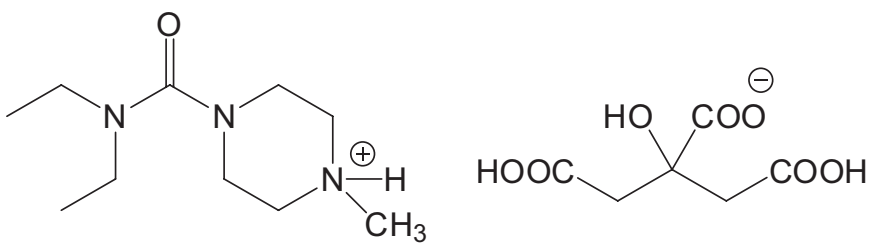

FIGURE 1 - Structure of diethylcarbamazine citrate.

Other than these official methods, a variety of techniques have been reported for the determination of DEC in pharmaceutical dosage forms, and include gas chromatography [GC] (Ramana, Raghuveer, Khadgapathi, 1986; Nene, Anjaneyalu, Rajagopalan, 1984; Pfaff, Gayral, Mahuzier, 1978; Joseph, Lawrence, 2001), high performance liquid chromatography [HPLC] (Mathew, Kalyanasundaram, 2001; Reddy et al., 2011; Krishna Vamsi et al., 2012), proton magnetic resonance [PMR] spectroscopy (El-Obeid, 1984, Jezzy et al., 1996), DC polarography analysis (Walash et al., 1985), ion selective electrode potentiometry (Campbell et al., 1980) and titrimetry (Abigail et al., 2011; Bhanumathi et al., 1981). However, many of the reported methods for DEC, particularly, the chromatographic methods are complex, requiring expensive instrumental set up and skilled operator which are not always found in laboratories of developing and under developed countries. Thus, the need for a simple, selective and low-cost method is obvious, especially for routine quality control analysis of pharmaceuticals containing DEC.

Several spectrophotometric methods based on diverse chemical reactions are found in the literature for DEC. Charge-transfer complex formed with iodine was used by Wahbi, El-Obeid, Gad-Kariem (El-Obeid, Gad-Kariem, 1986), for the assay of 1-6 $\mu \mathrm{g} \mathrm{mL} \mathrm{m}^{-1} \mathrm{DEC}$ in tablets. Chloranilic acid has been employed by two groups of workers (Rizk, Walash, Ibrahim, 1984; Michael, Kenneth, Anthony, 1999) as CT complexing agent for the assay of drug in pharmaceuticals based on the same type of reaction. In a method reported by Basu and Dutta (1961), the ion associate formed by DEC with ammonium reineckate at $\mathrm{pH} 3.5$ was filtered, dissolved in acetone and absorbance measured at $525 \mathrm{~nm}$. The colored condensation product (Refaat et al., 1987) formed by malonic acid with acetic anhydride in the presence of DEC was measured at $333 \mathrm{~nm}$ facilitating the assay of the drug in dosage forms. In a similar method (Bulbule, Kasture, Wadodkar, 1981), the base form of the drug was reacted with malonic acid and acetic anhydride at $80^{\circ} \mathrm{C}$ for $30 \mathrm{~min}$ and the resulting condensation product was measured at $334 \mathrm{~nm}$. The yellow colored condensation product (Bhuee et al., 1981) formed by an acetous solution of DEC with acetic anhydridepyridine mixture was measured at $428 \mathrm{~nm}$ and used for the determination of DEC in $10-100 \mu \mathrm{g} \mathrm{mL}^{-1}$ range in commercial tablets.

There are three reports on the use of ion-pair complexation reactions for the spectrophotometric assay of DEC. Rao and Subramanyam (1970) employed bromophenol blue at acidic $\mathrm{pH}$ as the ion pair complexing agent for the determination of the drug in tablets and biological fluids. The drug in tablets, syrups and parenterals was determined by extracting the ion-pair complex formed with bromocresol green (Vadodaria, Vora, Mukherji, 1968) at $\mathrm{pH} 4.6$ with chloroform. The colored complexes of the drug with Fast green FCF at pH 5.0 and orange II in $0.1 \mathrm{M}$ $\mathrm{HCl}$ were successfully employed by Sastry et al. (1988), for the determination of DEC in bulk drug and pharmaceutical preparations by extractive spectrophotometry.

The reported spectrophotometric methods suffer from one or the other disadvantage such as poor sensitivity and narrow linear range (Michael, Kenneth, Anthony, 1999), tedious and time-consuming steps like precipitation, filtration and washing (Basu, Dutta, 1961), heating (Refaat et al., 1987; Bulbule, Kasture, Wadodkar, 1981; Bhuee et al., 1981). The extraction methods (Rao, Subrahmanyam, 1970; Vadodaria, Vora, Mukherji, 1968; Sastry et al., 1988) though sensitive suffer from disadvantages like laborious liquid-liquid extraction step, critical $\mathrm{pH}$ adjustment, critical dependence on $\mathrm{pH}$ of the aqueous phase and the aqueous-organic phase's ratio. Additionally, incomplete extraction of the analyte may lead to erratic results. Hence, there is a need for developing a method free from such disadvantages.

The aim of the present study was directed at developing and validating simple, rapid, sensitive, costeffective titrimetric and two spectrophotometric methods 
using iodate and iodide as reagents. Iodide of the mixture present is oxidized by iodate in an amount equivalent to the $\mathrm{COOH}$ group present in citrate in DEC to iodine and the liberated iodine is determined. The methods were successfully applied to quantify DEC in pharmaceutical formulations.

\section{MATERIAL AND METHODS}

\section{Apparatus}

A Systronics model 166 digital spectrophotometer (Systronics, Ahmedabad, Gujarat, India) with matched 1 -cm quartz cells was used for absorbance measurements.

\section{Reagents and standards}

All chemicals used were of analytical reagent grade and distilled water was used to prepare solutions.

\section{Potassium iodate}

A high purity grade of the chemical (Merck, Mumbai, India) was used. A saturated solution of potassium iodate was prepared by stirring approximately $20 \mathrm{~g}$ of the chemical in a beaker containing $100 \mathrm{~mL}$ water with the help of magnetic stirrer for 60 minutes. The solution was decanted and filtered using quantitative filter paper.

\section{Potassium iodide}

A saturated solution of potassium iodide (Merck, Mumbai, India) was prepared just before use in order to prevent atmospheric oxidation to iodide.

\section{Sodium thiosulphate}

A $0.01 \mathrm{~N}$ sodium thiosulphate (S.D. Fine Chem., Mumbai, India) was prepared by dissolving $1.25 \mathrm{~g}$ in $500 \mathrm{~mL}$ water and standardized against $0.01 \mathrm{~N}$ potassium dichromate (Vogel, 1961).

\section{lodine solution}

A $0.01 \mathrm{~N}$ iodine solution (Merck, Mumbai, India) was prepared by dissolving $5 \mathrm{~g}$ of iodate-free potassium iodide in $30-40 \mathrm{~mL}$ of water in a glass stoppered $500 \mathrm{~mL}$ calibrated flask. Weighed out $0.63 \mathrm{~g}$ of analytical reagent (AR) grade or resublimed iodine on a watch glass and transferred into a flask containing concentrated potassium iodide by means of a small dry funnel, inserted the glass stopper into the flask, and shaken well in the cold condition until all the iodine has dissolved. Allowed the solution to acquire room temperature, and made up to mark with distilled water in a $500 \mathrm{~mL}$ calibrated flask (Vogel, 1961).

\section{Saturated Borax}

Approximately $30 \mathrm{~g}$ of borax (S.D. Fine Chem., Mumbai, India) were dissolved in $100 \mathrm{~mL}$ water and stirred with the help of magnetic stirrer for 15 minutes. The solution was decanted and filtered. The $\mathrm{pH}$ of the solution was between 8 and 9 .

\section{$1 \%$ starch}

Made a paste of $1 \mathrm{~g}$ of the soluble starch (Potato starch, Loba Chemie, Mumbai, India) with a little water, and poured the paste with constant stirring, into $100 \mathrm{~mL}$ of boiling water, and boiled for $1 \mathrm{~min}$., allowed the solution to cool before use and prepared afresh every day (Vogel, 1961).

\section{Standard drug solution}

Pharmaceutical grade DEC (99.7 per cent pure) was procured from Inga Laboratories Pvt. Ltd., Mumbai, India, and was used as received. Banocide forte tablets (Glaxo Smith Kline Pharma. Ltd., Nashik, India) and Banocide syrup (Glaxo Smith Kline Pharma. Ltd., Bangalore, India) both were purchased from local commercial stores.

A stock standard solution equivalent to $1 \mathrm{mg} \mathrm{mL}^{-1}$ DEC for method A was prepared by dissolving $250 \mathrm{mg}$ of pure drug in water and diluting to $250 \mathrm{~mL}$ in calibrated flask with water. The stock solution was diluted appropriately to get working concentration of $100 \mu \mathrm{g} \mathrm{mL}^{-1}$ with water for spectrophotometric methods.

\section{Recommended procedures}

\section{Method A}

A $10 \mathrm{~mL}$ aliquot of pure DEC solution containing 2-10 mg of DEC was taken in an Erlenmeyer flask. Five $\mathrm{mL}$ each of saturated solutions of $\mathrm{KIO}_{3}$ and $\mathrm{KI}$ followed by $10 \mathrm{~mL}$ thiosulfate (accurately measured) were added and the flask was stoppered and let stand for 10 min with occasional swirling. Finally, $1 \mathrm{~mL}$ of $1 \%$ starch indicator was added and unreacted thiosulfate was titrated against standard iodine solution until the decoloration of blue color.

The amount of DEC was calculated from the following formula:

$$
\text { Amount }(\mathrm{mg})=\frac{\left\{(\mathrm{B}-\mathrm{S}) \times \mathrm{M}_{\mathrm{W}} \times \mathrm{C}\right\}}{\mathrm{n}}
$$

where, $\mathrm{B}=$ volume of iodine consumed in the blank titration, $\mathrm{mL} ; \mathrm{S}=$ volume of iodine consumed in the sample titration, $\mathrm{mL} ; \mathrm{Mw}=$ relative molecular mass of $\mathrm{DEC} ; \mathrm{C}=$ molar concentration of thiosulfat; $n=$ number of moles of iodine reacting with each mole of DEC. 


\section{Method B}

Varying aliquots $(0.25-5.0 \mathrm{~mL})$ of $100 \mu \mathrm{g} \mathrm{mL}^{-1} \mathrm{DEC}$ was added in to a series of $10 \mathrm{~mL}$ calibrated flasks by

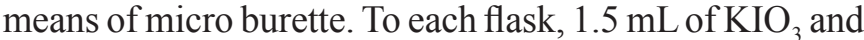
$1 \mathrm{~mL}$ of KI were added flasks stoppered, content mixed and let stand for $15 \mathrm{~min}$. Then $1 \mathrm{~mL}$ of saturated borax was added and made up to the mark with water. Absorbance of each solution was measured at $370 \mathrm{~nm}$ against reagent blank.

\section{Method C}

Different volumes (0.2-3.0 $\mathrm{mL})$ of $100 \mu \mathrm{g} \mathrm{mL}^{-1} \mathrm{DEC}$ were taken in a series of $10 \mathrm{~mL}$ calibrated flasks. One $\mathrm{mL}$ each of saturated $\mathrm{KIO}_{3}$ and $\mathrm{KI}$ solutions were added, flasks were stoppered and content mixed. The flasks were let stand for $15 \mathrm{~min}$ before adding $1 \mathrm{~mL}$ of saturated borax and $1 \mathrm{~mL}$ of $1 \%$ starch to each flask and finally made up to $10 \mathrm{~mL}$ with water. Absorbance of each solution was measured at $570 \mathrm{~nm}$ against reagent blank.

Standard graph was prepared by plotting the absorbance versus drug concentration, and the concentration of the unknown was computed from the respective regression equation.

\section{Procedure for tablets}

Twenty tablets were weighed accurately and ground into a fine powder. An accurately weighed amount of the powdered tablet equivalent to $100 \mathrm{mg}$ of DEC was transferred into a $100 \mathrm{~mL}$ calibrated flask. Sixty $\mathrm{mL}$ water was added and the content was shaken thoroughly for 15$20 \mathrm{~min}$ to extract the drug into the liquid phase; the volume was finally diluted to the mark with water, mixed well and filtered using a Whatman No. 42 filter paper. An aliquot of the filtrate (1 $\left.\mathrm{mg} \mathrm{mL}^{-1} \mathrm{DEC}\right)$ was used for method A and diluted to required concentrations and used for the assay in method $\mathrm{B}$ and method $\mathrm{C}$ as described above.

\section{Procedure for syrup}

The content of five $100 \mathrm{~mL}$ syrup bottles was pooled and $5 \mathrm{~mL}$ syrup containing $120 \mathrm{mg}$ DEC was taken and its solution prepared as described in 'procedure for tablets'. This $1.2 \mathrm{mg} \mathrm{mL}^{-1} \mathrm{DEC}$ syrup extract was further diluted to get working standard solution of $100 \mu \mathrm{g} \mathrm{mL}^{-1}$ for method $\mathrm{B}$ and method $\mathrm{C}$ with water and analyzed by taking an appropriate volume in all the methods.

Procedure for the analysis of placebo blank and synthetic mixture

A placebo blank containing starch $(45 \mathrm{mg})$, acacia $(35 \mathrm{mg})$, sodium citrate $(40 \mathrm{mg})$, hydroxyl cellulose (45 mg), magnesium stearate $(50 \mathrm{mg})$, talc $(40 \mathrm{mg})$ and sodium alginate $(35 \mathrm{mg}$ ) was prepared by mixing all the components into a homogeneous mixture. A $100 \mathrm{mg}$ of the placebo blank was accurately weighed and its solution was prepared as described under 'tablets', and then subjected to analysis by following the general procedures.

To $50 \mathrm{mg}$ of the placebo blank of the composition described above, $100 \mathrm{mg}$ of DEC was added and homogenized, transferred to a $100 \mathrm{~mL}$ calibrated flask and the solution was prepared as described under "Procedure for tablets", and then subjected to analysis by the procedure described above. This analysis was performed to study the interference by excipients normally present in tablet preparation.

\section{RESULTS AND DISCUSSION}

Preliminary experiments showed that DEC is sufficiently acidic to release iodine from iodate-iodide mixture allowing the titrimetric and spectrophotometric determination of drug. Iodide present is oxidized by iodate in an amount equivalent to the $\mathrm{COOH}$ group present in citrate in DEC to iodine and the liberated iodine is determined. In titrimetry, the liberated iodine was reacted with a measured excess of thiosulphate and residual reductant was titrated with iodine and the end point being located visually with starch, while in spectrophotometry, it was determined by two different color reactions.

\section{Method development}

\section{Method A}

The quantitative nature of the reaction between DEC and iodate-iodide reagent was checked by treating 2.0-10.0 $\mathrm{mg}$ of drug with an excess of reagent and determining the iodine released. For the range studied (2.0-10.0 mg), $5.0 \mathrm{~mL}$ each of saturated solution of iodate and iodide and reaction time of $10 \mathrm{~min}$ were found adequate. The end point was located visually using starch. The reaction stoichiometry is 1:3 (drug: liberated iodine), the $\mathrm{COOH}$ group in the citrate is acidic enough to liberate iodine.

$$
\begin{gathered}
\mathrm{IO}_{3}^{-}+5 \mathrm{I}^{-}+6 \mathrm{H}^{+}(\mathrm{DEC}) \rightarrow 3 \mathrm{I}_{2}+3 \mathrm{H}_{2} \mathrm{O} \\
\mathrm{I}_{2}+3 \mathrm{Na}_{2} \mathrm{~S}_{2} \mathrm{O}_{3} \text { (excess) } \rightarrow 2 \mathrm{NaI}+\mathrm{Na}_{2} \mathrm{~S}_{4} \mathrm{O}_{6}+\text { unreacted } \mathrm{Na}_{2} \mathrm{~S}_{2} \mathrm{O}_{3} \\
\text { unreacted } \mathrm{Na}_{2} \mathrm{~S}_{2} \mathrm{O}_{3}+\text { starch }><\text { Iodine }
\end{gathered}
$$

Method B and method C

Absorbance of the liberated iodine or starch-iodine complex was measured at 370 or $570 \mathrm{~nm}$ as deduced from the absorption spectra of the colored species (Figure 2a and $2 \mathrm{~b}$ ). In both methods, the reaction was relatively fast 
in the beginning and iodine continued to be liberated even after $15 \mathrm{~min}$. Since most of the iodine was liberated within $15 \mathrm{~min}$, the reaction was stopped by adding borax to the reaction mixture after a standing time of $15 \mathrm{~min}$. The absorbance remained constant for 25 and $45 \mathrm{~min}$ in method B and method C, respectively. Attempts to hasten the reaction by heating were unsuccessful owing to the volatility of iodine and dissociation of iodine-starch complex at elevated temperature.
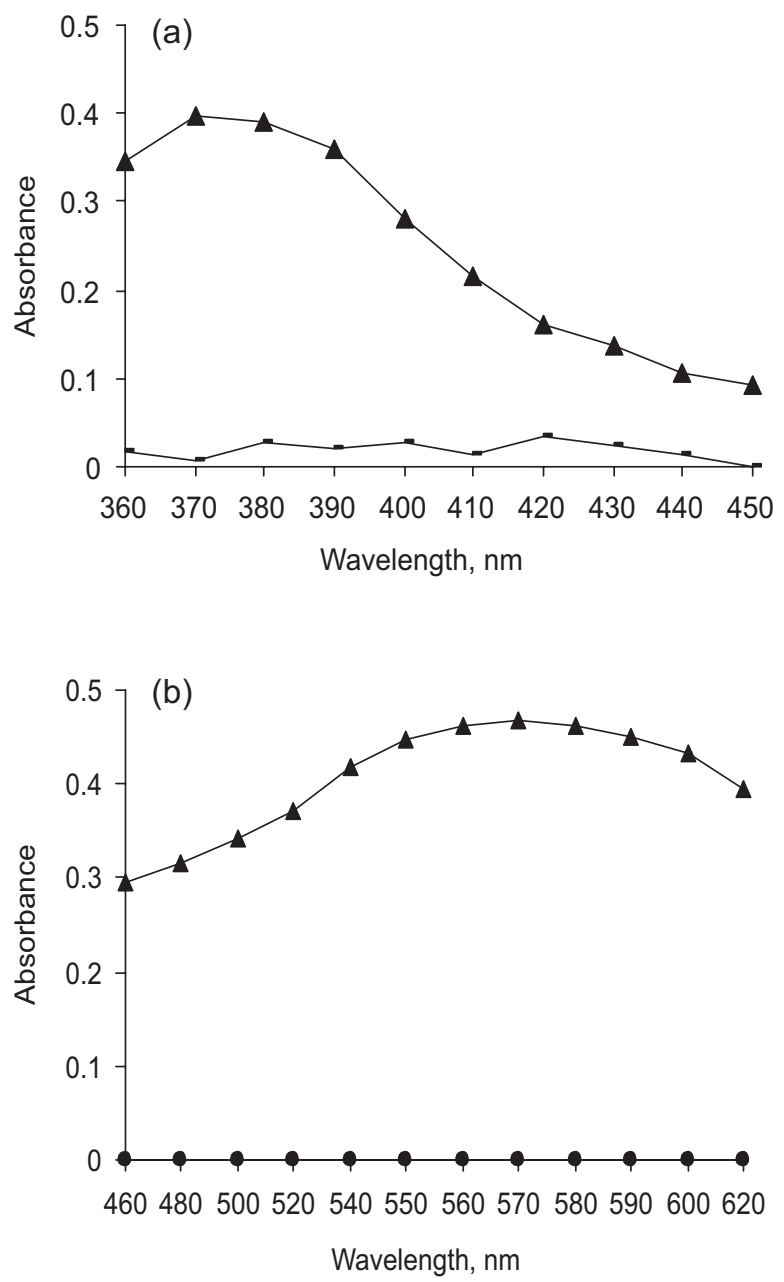

FIGURE 2- (a) Absorption spectra of DEC-iodide complex ( $\boldsymbol{\Delta}$ ) $\left[20 \mu \mathrm{g} \mathrm{mL}^{-1}\right.$ DEC] and blank (-); (b) Absorption spectra of DECiodine-starch complex $(\boldsymbol{\Delta})\left[20 \mu \mathrm{g} \mathrm{mL} \mathrm{mL}^{-1} \mathrm{DEC}\right]$ and blank

The possible reaction schemes responsible for change in absorbance as a function of DEC concentration are represented below:

$$
\begin{gathered}
\mathrm{IO}_{3}^{-}+5 \mathrm{I}^{-}+6 \mathrm{H}^{+}(\mathrm{DEC}) \rightarrow 3 \mathrm{I}_{2}+3 \mathrm{H}_{2} \mathrm{O} \\
(\text { Method B: measured at } 370 \mathrm{~nm}) \\
\mathrm{I}_{2}+\text { Starch } \rightarrow \mathrm{I}_{2}-\text { Starch complex } \\
(\text { Method C: measured at } 570 \mathrm{~nm})
\end{gathered}
$$

\section{VALIDATION PROTOCOL}

Linearity, detection and quantification limits

Under the optimum conditions, a linear relation was obtained between absorbance and concentration of DEC in the ranges given in Table I. The calibration graph in each instance is described by the equation:

$$
\mathrm{Y}=\mathrm{a}+\mathrm{b} \mathrm{X}
$$

where $\mathrm{Y}=$ absorbance, $\mathrm{a}=$ intercept, $\mathrm{b}=$ slope and $\mathrm{X}=$ concentration in $\left.\mu \mathrm{g} \mathrm{mL}^{-1}\right)$. The correlation coefficient, intercept and slope for the calibration data are summarized in Table I. Sensitivity parameters such as apparent molar absorptivity and Sandell sensitivity values, the limits of detection (LOD) and quantification (LOQ) are calculated as per the current $I C H$ guidelines (ICH guidelines, 1996) and compiled in Table I. LOD and LOQ were calculated according to the same guidelines using the following formulae:

$$
L O D=\frac{3.3 \times \sigma}{S} \& L O Q=\frac{10 \times \sigma}{S}
$$

where $\sigma$ is the standard deviation of six reagent blank determinations and $\mathrm{s}$ is the slope of the calibration curve, also molar absorptivity $(\varepsilon)$ and Sandell sensitivity (SS) were calculated using the relation;

$$
\varepsilon=\frac{\Delta \mathrm{A} \times \mathrm{M}_{\mathrm{W}} \times 10^{3}}{\mathrm{ppm}} \& \mathrm{SS}=\frac{0.001 \times \mathrm{M}_{\mathrm{W}} \times 10^{9}}{\varepsilon \times 1000}
$$

where $\Delta \mathrm{A}$ is the change in absorbance, $\mathrm{Mw}$ is the molecular weight of DEC and ppm is the concentration of DEC.

\section{Selectivity}

The results obtained from placebo blank and synthetic mixture analyses revealed that inactive ingredients used in the tablet preparation did not interfere in the assay of active ingredient. The absorbance values obtained from the placebo blank solution were almost equal to the absorbance of the blank which revealed no interference from the adjuvants. To study the role of additives added to the synthetic sample, the analysis of synthetic mixture solution prepared as described earlier yielded percent recoveries of $98.9 \pm 2.13,99.2 \pm 1.36$ and $102.31 \pm 1.29(\mathrm{n}=5)$ for method A, method B, and method C, respectively. This demonstrates the accuracy as well as the precision of the proposed methods and complements the findings of the placebo blank analysis with respect to selectivity.

\section{Precision}

The precision of the method was calculated in terms 
TABLE I - Sensitivity and regression parameters of spectrophotometric methods

\begin{tabular}{lcc}
\hline Parameter & Method B & Method C \\
\hline$\lambda_{\text {max }}, \mathrm{nm}$ & 370 & 570 \\
Color stability, min. & $\geq 20$ & $\geq 60$ \\
Linear range, $\mu \mathrm{g} \mathrm{mL}-1$ & $2.5-50$ & $2.5-30$ \\
Molar absorptivity $(\varepsilon), \mathrm{L} \mathrm{mol}^{-1} \mathrm{~cm}^{-1}$ & $6.48 \times 10^{3}$ & $9.96 \times 10^{3}$ \\
Sandell sensitivity*, $\mu \mathrm{g} \mathrm{cm}^{-2}$ & 0.0604 & 0.0393 \\
Limit of detection (LOD), $\mu \mathrm{g} \mathrm{mL}-1$ & 0.25 & 0.11 \\
Limit of quantification $(\mathrm{LOQ}), \mu \mathrm{g} \mathrm{mL}-1$ & 0.75 & 0.33 \\
Regression equation, $\mathrm{Y}^{* *}$ & & \\
Intercept (a) & 0.0126 & 0.0786 \\
Slope (b) & 0.0169 & 0.0337 \\
Standard deviation of a $\left(\mathrm{S}_{\mathrm{a}}\right)$ & $9.98 \times 10^{-2}$ & $9.98 \times 10^{-2}$ \\
Standard deviation of $\mathrm{b}\left(\mathrm{S}_{\mathrm{b}}\right)$ & $2.24 \times 10^{-3}$ & $3.98 \times 10^{-3}$ \\
Regression coefficient $(\mathrm{r})$ & 0.9974 & 0.9939 \\
\hline
\end{tabular}

*Limit of determination as the weight in $\mu \mathrm{g} \mathrm{mL}^{-1}$ of solution, which corresponds to an absorbance of $\mathrm{A}=0.001$ measured in a cuvette of cross-sectional area $1 \mathrm{~cm}^{2}$ and $\mathrm{l}=1 \mathrm{~cm} .{ }^{* *} \mathrm{Y}=\mathrm{a}+\mathrm{bX}$, Where $\mathrm{Y}$ is the absorbance, $\mathrm{X}$ is concentration in $\mu \mathrm{g} \mathrm{mL}{ }^{-1}$, a is intercept and $\mathrm{b}$ is slope.

of intermediate precision (intra-day and inter-day) ( $\mathrm{ICH}$ guidelines, 1996). Three different concentration of DEC were analyzed in seven replicates during the same day (intra-day precision) and five consecutive days (inter-day precision). The RSD (\%) values of intra-day and inter-day studies showed that the precision was good (Table II).

\section{Accuracy}

The accuracy of an analytical method expresses the closeness between the reference value and the found value. Accuracy was evaluated as percentage relative error between the measured concentrations and taken concentrations for DEC. The results obtained are compiled in Table II and show that the accuracy is satisfactory for all the methods.

\section{Application to analysis of tablets and syrup}

The proposed methods were applied to determine DEC in one brand each of tablets and syrup. The results were statically compared with those obtained by the official

TABLE II - Evaluation of Intra-day and inter-day accuracy and precision

\begin{tabular}{|c|c|c|c|c|c|c|c|}
\hline \multirow[b]{2}{*}{ Method } & \multirow{2}{*}{$\begin{array}{l}\text { *DEC } \\
\text { Taken }\end{array}$} & \multicolumn{3}{|c|}{ Intra-day accuracy and precision $(n=7)$} & \multicolumn{3}{|c|}{ Inter-day accuracy and precision $(n=7)$} \\
\hline & & $\begin{array}{c}\text { *DEC } \\
\text { Found }^{\mathrm{a}}\end{array}$ & $\begin{array}{c}\text { RSD }^{\mathbf{b}} \\
\%\end{array}$ & $\begin{array}{c}\mathrm{RE}^{\mathrm{c}} \\
\%\end{array}$ & $\begin{array}{l}\text { *DEC } \\
\text { found }\end{array}$ & $\begin{array}{c}\text { RSD }^{\mathbf{b}} \\
\%\end{array}$ & $\begin{array}{c}\mathbf{R E}^{\mathrm{c}} \\
\%\end{array}$ \\
\hline \multirow{3}{*}{ A } & 3.0 & 2.95 & 1.02 & 1.67 & 2.93 & 1.54 & 2.33 \\
\hline & 6.0 & 5.89 & 1.76 & 1.73 & 5.81 & 2.58 & 3.26 \\
\hline & 9.0 & 8.89 & 0.95 & 1.11 & 9.11 & 1.29 & 1.22 \\
\hline \multirow{3}{*}{ B } & 10 & 9.83 & 1.69 & 1.73 & 9.78 & 2.46 & 2.76 \\
\hline & 20 & 19.71 & 1.44 & 0.95 & 19.65 & 1.74 & 3.54 \\
\hline & 30 & 29.43 & 1.88 & 1.54 & 29.14 & 2.85 & 3.26 \\
\hline \multirow{3}{*}{$\mathrm{C}$} & 15 & 14.79 & 1.54 & 1.40 & 14.71 & 1.49 & 1.94 \\
\hline & 20 & 19.69 & 0.97 & 1.55 & 19.63 & 2.13 & 1.85 \\
\hline & 25 & 24.72 & 1.29 & 1.12 & 24.69 & 1.81 & 1.24 \\
\hline
\end{tabular}

DEC-diethylcarbamazine citrate. ${ }^{*} \mathrm{mg}$ in method $\mathrm{A}$ and $\mu \mathrm{g} \mathrm{mL}{ }^{-1}$ in methods $\mathrm{B}$ and $\mathrm{C} ;{ }^{\mathrm{a}}$ Mean value of 7 determinations; ${ }^{\mathrm{b}}$ Relative standard deviation (\%); ${ }^{\mathrm{c}}$ Relative error $(\%)$. 
British Pharmacopoeia (1988) method, which describes a non-aqueous titration method for its determination for accuracy and precision by applying the Student's $t$-test and variance ratio $F$-test. Statistical analysis of the results using Student's $t$-test for accuracy and $F$-test for precision revealed no significant difference between the proposed methods and the official method at the $95 \%$ confidence level with respect to accuracy and precision (Table III).

The accuracy and validity of the proposed methods were further ascertained by performing recovery studies. Pre-analyzed tablet powder was spiked with pure DEC at three concentration levels $(50,100$ and $150 \%$ of that in tablet powder) and the total was found by the proposed methods. In all cases, the added DEC recovery percentage values ranged 98.9-102.7 with a standard deviation of 0.791.82. The results of this study given in Table IV indicated that the recovery was good, and that the co-formulated substances did not interfere in the determination.

TABLE III - Results of analysis of formulations by the proposed methods

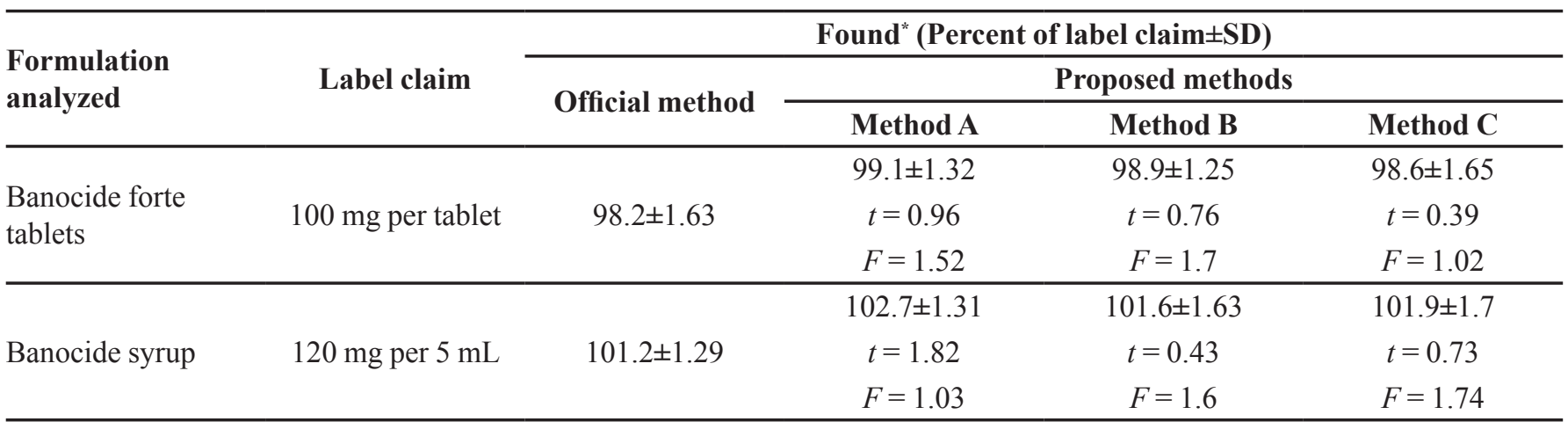

${ }^{*}$ Mean value of five determinations. Tabulated $t$-value at the $95 \%$ confidence level is 2.77 . Tabulated $F$-value at the $95 \%$ confidence level is 6.39 .

TABLE IV - Results of recovery study via standard addition technique

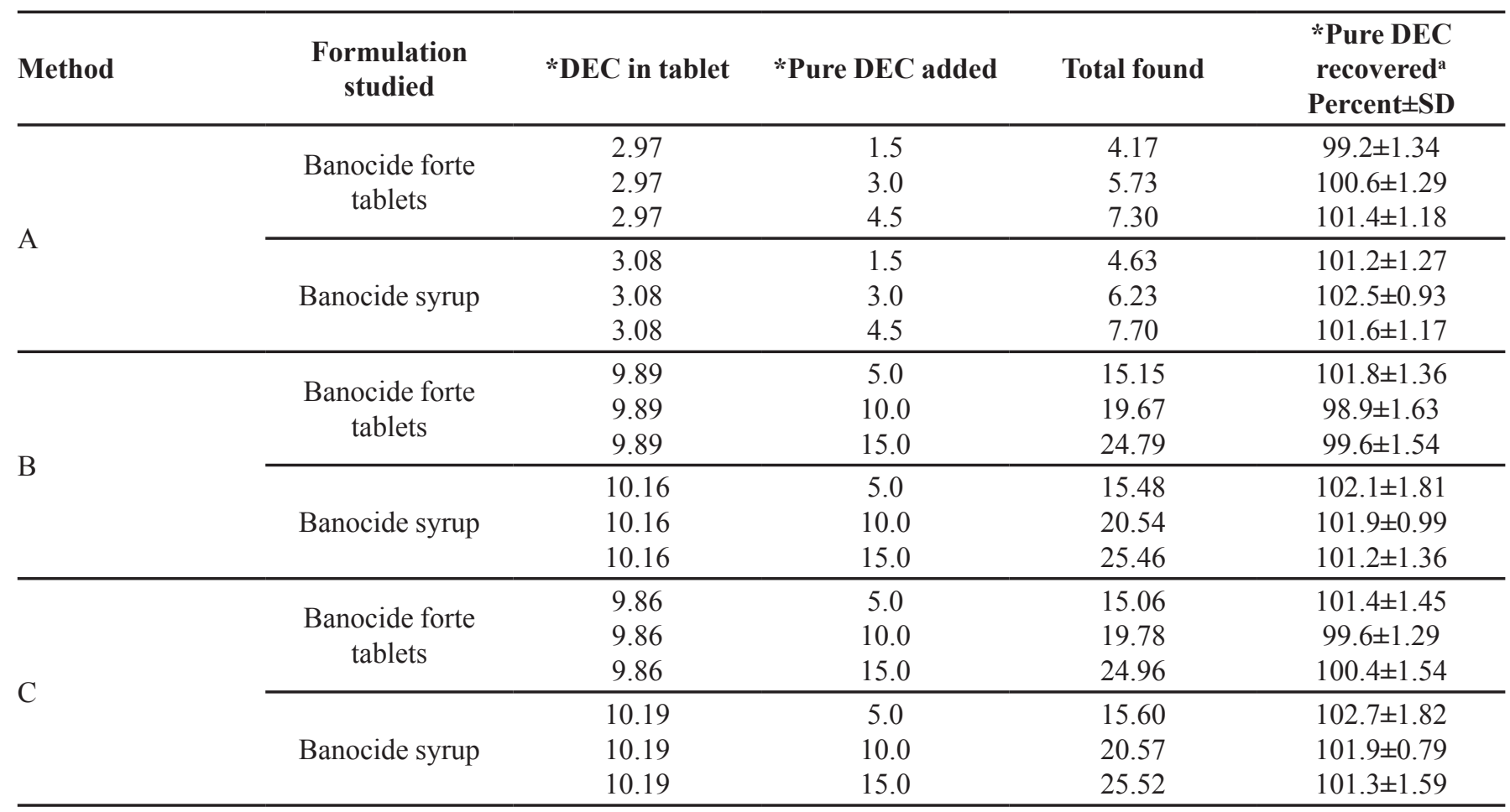

*mg in method $\mathrm{A}$ and $\mu \mathrm{g} \mathrm{mL} \mathrm{mL}^{-1}$ in methods $\mathrm{B}$ and $\mathrm{C}$; ${ }^{\mathrm{a}}$ Mean value of three determinations. 


\section{CONCLUSIONS}

Three methods have been developed for determination of DEC in bulk drug and in its dosage forms and validated as per the current $\mathrm{ICH}$ guidelines. The methods use cheap and readily available chemicals, compared to the lone titrimetric method [official method], the presented methods are rather simple and sensitive. The reported methods suffer from such draw backs as high cost, and several clean-up steps. They are time-consuming and often poorly reproducible, some require toxic organic solvents. Any method chosen for routine analysis should be reasonably simple, used materials should be readily available in the laboratory or readily obtainable, and require a minimum amount of equipment. The methods are selective as none of the common tablet excipients contain acidic groups to interfere with the present proposed methods. The proposed spectrophotometric methods are free from rigid experimental variables such as $\mathrm{pH}$ control, heating or extraction step and/or use of organic solvents. They are characterized by high selectivity and comparable sensitivity with respect to the existing methods (Table V).

TABLE V - Comparison of performance characteristics of the present methods with the existing methods

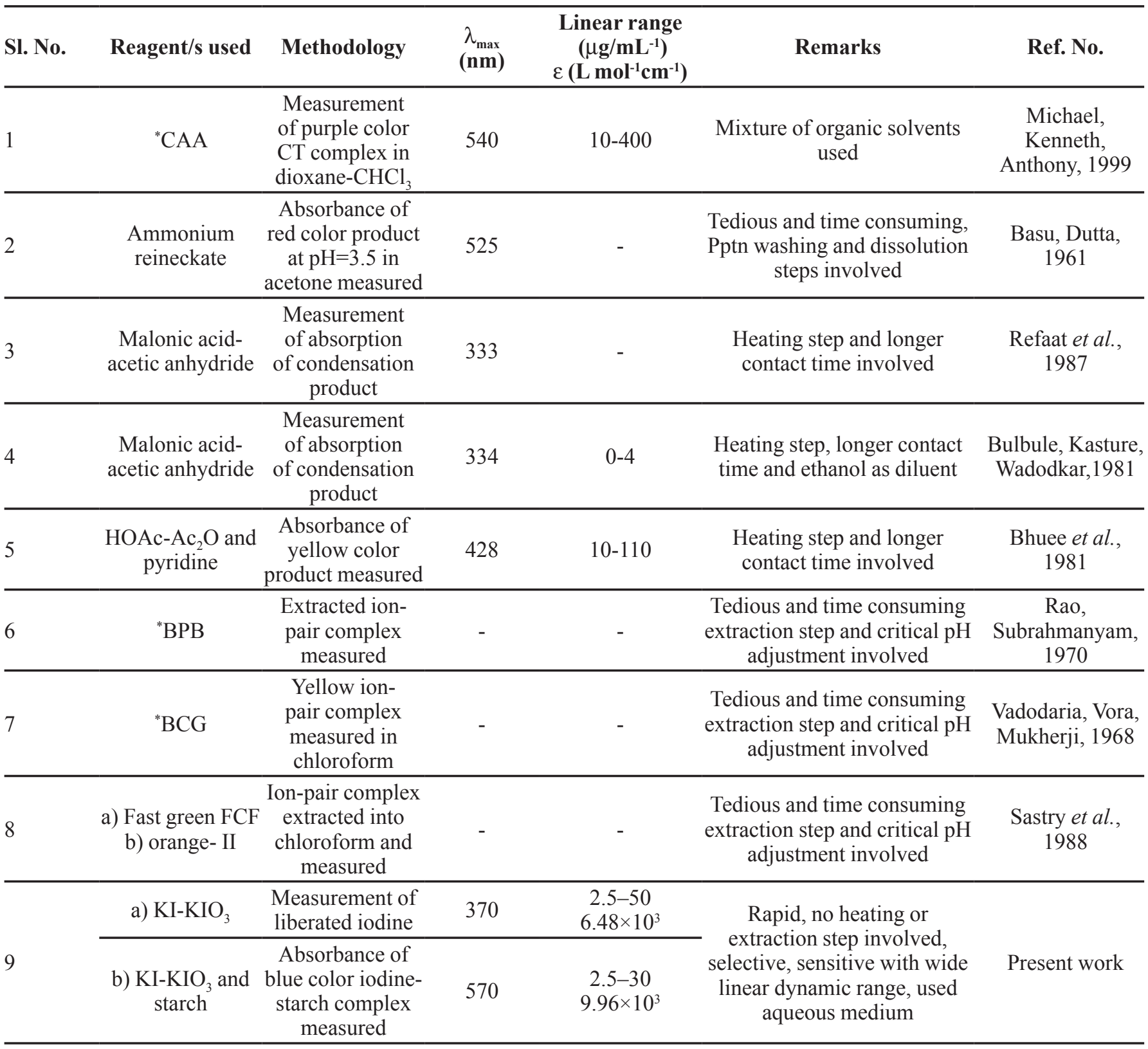

* CAA-chloranilic acid, BCG-bromocresol green, BPB-bromophenol blue, BTB-bromothymol blue 


\section{ACKNOWLEDGEMENTS}

Authors are grateful to the quality control manager, Inga Laboratories Pvt. Ltd., Mumbai, India, for gift sample of pure diethylcarbamazine citrate and the authorities of the University of Mysore, Mysore, for permission and facilities. Prof. K. Basavaiah is indepted to the University Grants Commission, New Delhi, India, for the award of BSR faculty fellowship.

\section{REFERENCES}

ABIGAIL, W.; PATRICK, B.; SHANNON, H.; MARCO, M.; BRENNAN, E.B.; DOMINIQUE, M.; THOMAS, G.S.; MARYA, L. A low-tech analytical method for diethylcarbamazine citrate in medicated salt. PLoS Negl. Trop. Dis., v.5, p.e1005, 2011.

ADKIWU, M. U.; OFOKANSI, K. C.; ATTAMA, A. A. Spectrophotometric and thermodynamic studies of the charge-transfer interaction between Diethylcarbamazine Citrate and Chloranilic Acid. Chem. Pharm. Bull., v.47, p.463-466.

BASU, K.; DUTTA, B.N. A rapid colorimetric method of estimation of diethyl-carbamazine citrate in pharmaceutical preparations. Ind. J. Pharm., v.23, p.326-329, 1961.

BHANUMATHI, L.; WADODKAR, S.G.; KASTURE, A.V. Methods for analysis of diethylcarbamazine citrate. Indian Drugs, v.8, p.204-206, 1981.

BHUEE, G.S.; RASTOGI, S.N.; JETLEY, U.K.; JAI SINGH. Colorimetric determination of diethylcarbamazine citrate. East. Pharm., v.24, p.197-198, 1981.

BULBULE, M.V.; KASTURE, A.V.; WADODKAR, S.G. A note on spectrophotometric determination of diethylcarbamazine citrate. Indian Drugs, v.19, p.27-28, 1981.

CAMPBELL, M.J.M.; DEMETRIOU, B.; JONES, R. Assay of procyclidine hydrochloride, cyclizine hydrochloride, and diethylcarbamazine citrate in tablets using ion-responsive electrodes. Analyst, v.105, p.605-611, 1980.

EL-OBEID, A.H. Determination of diethylcarbamazine citrate in tablets by proton magnetic resonance. Spectr. Lett., v.17, p.361-367, 1984.
INTERNATIONAL CONFERENCE ON HARMONIZATION.

ICH. Technical requirements for registration of pharmaceuticals for human use harmonised tripartite guideline. Validation of Analytical Procedures: Text and Methodology Q2(R1). London 2005.

JEZZY, W.; JAROSZEWSKI, D.B.; FRANK, A.; SIMONSEN, S.P.E.; METTE, K.; AGGER. Determination of diethylcarbamazine, an antifilarial drug, in human urine by 1H-NMR spectroscopy. J. Pharm. Biomed. Anal., v.14, p.543-549, 1996.

JOSEPH, R.M.; LAWRENCE, F. Gas chromatographic assay of diethylcarbamazine in human plasma for application to clinical pharmacokinetic studies. J. Pharm. Biomed. Anal., v.26, p.665-674, 2001.

KRISHNA VAMSI, M.; JAYALAKSHMI, B.; VIJAY, R.A.; SANDEEP, C. A sensitive RP-HPLC method for simultaneous estimation of diethylcarbamazine citrate and levoceterizine in bulk and pharmaceutical dosage form. Int. J. Pharm. Sci. Res., v.3, p.3347-3353, 2012.

MATHEW, N.; KALYANASUNDARAM, M. A high performance liquid chromatographic method for the estimation of diethylcarbamazine content in medicated salt samples. Acta. Trop., v.80, p.97-102, 2001.

MICHAEL, U.A.; KENNETH, C.O.; ANTHONY, A.A. Spectrophotometric and thermodynamic studies of the charge-transfer interaction between diethylcarbamazine citrate and chloranilic acid. Chem. Pharm. Bull., v.47, p.463-466, 1999.

NENE, S.; ANJANEYULU, B.; RAJAGOPALAN, T.G. Determination of diethylcarbamazine in blood using gas chromatography with alkali flame ionization detection. $J$. Chrom. Biomed. Appl., v.308, p.334-340, 1984.

PFAFF, M.C.; GAYRAL, P.; MAHUZIER, G. A method for the gas chromatographic determination of diethylcarbamazine (Hetrazan) in serum of laboratory rodents. J. Chromatogr., v.150, p.155-160, 1978 .

RAMANA, R.G.; RAGHUVEER, S.; KHADGAPATHI, P. Quantitative determination of diethylcarbamazine citrate and chlorpheniramine maleate in pharmaceutical dosage forms by gas liquid chromatography. Indian Drugs. v.24, p.37-41, 1986. 
RAO, K.N.; SUBRAHMANYAM, D. Estimation of diethylcarbamazine (hetrazan). Ind. J. Med. Res., v.58, p.746-752, 1970.

REDDY, J.M.; JEYAPRAKASH, M.R.; MADHURI, K.; MEYYANATHAN, S.N.; ELANGO, K. A sensitive RP-HPLC method for simultaneous estimation of diethylcarbamazine and levocetirizine in tablet formulation. Ind. J. Pharm. Sci., v.73, p.320-323, 2011.

REFAAT, I.H.; EL-KOMMOS, M.E.; FARAG, H.H.; ELRABAT, N.A. Spectrofluorometric and spectrophotometric determination of some tertiary amine drugs. Bull. Pharm. Sci, Assiut Univ., v.10, p.85-102, 1987.

RIZK, M.; WALASH, M.I.; IBRAHIM, F. Spectrophotometric determination of piperazine, piperazine salts and diethylcarbamazine citrate with chloranilic acid. Spectr. Lett., v.17, p.423-440, 1984.

SASTRY, C.S.P.; ARUNA, M.; REDDY, M.N.; SANKAR, D.G. Extractive spectrophotometric determination of some anthelmintics using Fast green FCF or Orange II. Ind. $J$. Pharm. Sci., v.50, p.140-142, 1988.

SWINYARD, E.A. Remington's Pharmaceutical Sciences. Easton: Mack Publishing Company, 1990. p.1242-1248.
THE BRITISH PHARMACOPOEIA. London: Her Majesty's Stationery Office, 1988. p. 190.

UNITED STATES PHARMACOPOEIA. Monographs. (USP30-NF25 p.1929), Pharmacopoeial forum, v.28, p.1098.

VADODARIA, D.J.; VORA, M.N.; MUKHERJI, P.S. Colorimetric estimation of diethylcarbamazine citrate in pharmaceutical preparations. Ind. J. Pharm., v. 30, p.4143, 1968.

VOGEL A.I. A text book of quantitative inorganic analysis, 3.ed. London: Longman, 1961. p.354.

WAHBI, A.M.; EL-OBEID, A.H.; GAD-KARIEM, E.A. Spectrophotometric determination of diethylcarbamazine citrate via charge-transfer complex. Farmaco Prat., v.41, p.210-214, 1986.

WALASH, M.I.; RIZK, M.S.; IBRAHIM, F.A. DC polarographic assay of piperazines. J. Assoc. Offic. Anal. Chem., v.68, p.532-534, 1985.

Received for publication on $20^{\text {th }}$ January 2014 Accepted for publication on $08^{\text {th }}$ May 2014 